\title{
THE DISCREET CHARM OF THE BELVEDERE: SUBMERGED HOMOSEXUALITY IN EIGHTEENTH-CENTURY WRITING ON ART
}

\author{
JEFF MORRISON
}

\begin{abstract}
This essay comprises an investigation of ekphrasis in the work of J. J. Winckelmann and particularly in his presentation of famous statues in the Vatican Belvedere courtyard collection. Key treatments of statues are revealed as offering much more than descriptions or art-historical analyses. Rather, they detail emerging relationships with works of art, relationships the dynamic nature of which is captured in the rhetoric of the descriptions. And like many good relationships these are informed by sex - but perhaps not in the obvious manner. It is more than a matter of Winckelmann taking a fancy to the objects he describes. Writing on art is revealed as an important site of repressed/submerged homosexuality. Following theoretical leads offered by Michel Foucault and Michael Worton, the essay investigates the disguised discursive existence of homosexuality in the rhetoric of aesthetics and explains its importance and subversive potential in a world where homosexuality cannot easily exist in the open; it then reflects upon the fact that in the apparently more liberated twentieth century, discussion of the sexual subtext to Winckelmann is still remarkable for its absence. Winckelmann is thus preserved in the literary/historical consciousness as the initiator of a rather arid brand of NeoClassicism - all noble simplicity and calm grandeur - when his own writing reveals opposite, more human qualities.
\end{abstract}

The body, and particularly the body as depicted in art, is one of the most important sites for the discussion of aesthetics. The Classical nude statue and its more modern variants in a variety of media have often had canonical status; they have come to embody not just stylistic norms of the given age but also aesthetic principles which could have value beyond their own age. And the aesthetic was often more or less directly connected to moral principles which were understood to inform the realm of art. Thus the famous Laocöon statue could be seen (misguidedly) as the perfect illustration of the stylistic simplicity and clarity of great Greek art. ${ }^{1}$ What is more, it can be seen as likely to promote stylistic improvements in the art of later periods exposed to it. It can be seen as an aesthetic incarnation of a brand of stoic philosophy which enables Laocöon in this representation to bear his own and his sons' suffering with dignity. In interpreting the statue in this way, I do so knowingly; the voice is not my own but something of a composite of representative eighteenth-century voices, not

\footnotetext{
${ }^{1}$ The statue is now generally regarded as representative of late Hellenistic baroque art. The very presence of the word 'baroque' in any stylistic categorisation of the statue would surely have been most painful to Winckelmann, since the Baroque was precisely what he was writing against. It shows that Winckelmann often saw what he wanted to see in art - and interestingly, from our point of view, that his writing often tells you more about him than about the given work of art.
} 
least Johann Joachim Winckelmann's. What is immediately clear is that a multitude of other perspectives upon this great work are possible, depending upon available critical methodologies and intentions. Whilst the mid-eighteenth-century example given is an important one, it is not only important for the obvious reasons. Yes, neo-classical taste as defined by Winckelmann and his followers had a measurable impact upon the art, the aesthetics and even by extension the literature of his and later eras. However, I will argue that the matter of why it did so is the more interesting question. It was not merely a question of the right man being in the right place at the right time with the right theory. Whilst there is some truth in the first three points, the theory was mostly already out of date. ${ }^{2}$ And almost all of his writing, which extends to twelve volumes of texts in the standard edition along with four volumes of correspondence, verges on the unreadable for the non-specialist; it certainly remains largely unread. ${ }^{3}$ More interesting from our point of view is then the matter of how Winckelmann presents his material in his well-known purple passages; it is certainly clear that his presentation of art is substantially different from that of his contemporaries. ${ }^{4}$ The language has a different character, partly because he was inventing a German language for aesthetics as he was going along (see below), but above all because it was driven by a different force: sex. Writing on art inevitably responds at some level to the fundamentally sensual nature of the objects and the initially sensual experience of them, but in Winckelmann it is rather more than this. This is no arid theoretical prose but dynamic, driven language, engaged language which reflects a developing relationship with art and which draws upon the repressed (homo-)sexuality of the author. His readers responded to it in his texts and in him, in his energetic guided tours around the great collections in Rome. Or rather they certainly identified the energy, if not its source. They might have been troubled if they had known the source, since it was a homosexuality with bisexual/paedophile tendencies. ${ }^{5}$

Below I will introduce once more the received view of Winckelmann in

\footnotetext{
${ }^{2}$ The best evidence of the heterogeneity of Winckelmann's writing is to be found in his notebooks, stored mostly in the Bibiothèque Nationale, Paris, Fonds allemands, 56-67.

${ }^{3}$ Johann Joachim Winckelmann, Sämtliche Werke: Einzige Vollständige Ausgabe, ed. Joseph Eiselein, Donaueschingen 1825-9; repr. Osnabrück 1965. Johann Joachim Winckelmann, Briefe, ed. Walther Rehm, Berlin 1952-7. (Further references to Rehm's edition will be found in the body of the text in the form: Briefe, vol. no., page no.) Perhaps the best example of his work being left unread is provided by Ernst Osterkamp who in a recent unpublished paper to Oxford postgraduates offered evidence that Goethe took out Winckelmann's Monumenti antichi inediti spiegati ed illustrati (Rome 1767), a massive volume, for a grand total of three days.

${ }^{4}$ The best working edition of these descriptions (in various versions) is to be found in Johann Joachim Winckelmann, Kleine Schriften, Vorreden, Entwürfe, ed. Walther Rehm, Berlin 1968. (Further references to this volume will be found in the body of the text in the form: $K S$, page no.)

${ }^{5}$ The documentary evidence of Winckelmann's sex life/sexual preferences is not plentiful but is clear. His preferences ranged from young adults like von Berg (see note 16, below) through young boys such as Niccolo Castellani (see note 17, below) to prepubescent girls such as a young dancer mentioned on a number of occasions.
}

(c) Blackwell Publishers Ltd 1999. 
cultural history but only in order to contrast this figure with the more important Winckelmann whose work is driven by a sexual energy which might otherwise have remained latent.

Johann Joachim Winckelmann is one of the many figures in German literary history whose place is central, if small. He appears in the early stages of most debates about the emergence of (Neo-)Classicism; he marks the starting-point of the Laocöon-debate for many critics and so is important in the development of aesthetic criteria generally. ${ }^{6}$ His contribution is, however, rarely the centre-piece of literary-historical discussion. We move swiftly on to Lessing, Goethe, Schiller, with only the one Winckelmannian formula sticking in our mind, the famous (if elusive) characterisation of the best Classical art as embodying 'edle Einfalt und stille Größe'. His position in art history is perhaps more substantial. His historical stylistics are seen as marking a starting-point for modern systematic art history, and his historical categories are still broadly applicable. He even slips into debates about the emergence of a dynamic German language of aesthetics, where his work is usually contrasted positively with Baumgarten's Latin treatises. None of these contributions is to be underrated, but none of the typical treatments of Winckelmann quite manages to explain his influence upon other intellectuals in whatever field. On reflection, even his position in literary history would seem in some ways difficult to account for. Whilst he wrote extensively about matters of taste, he wrote very little and very crudely about literature. His love of Geßner might make us slightly nervous about his reliability in these matters. ${ }^{8}$ His art history is a miraculous achievement because the information he had was incomplete and his historical categories were often inspired guesswork. ${ }^{9}$ His contribution to the German language is undoubted in historical terms, but this does not mean that his baroque sentence structures and uneasy combinations of German agricultural imagery and translation of classical rhetoric are easy on the reader. ${ }^{10}$ We must look elsewhere.

My search was aided by two pieces of connected theoretical material.

\footnotetext{
${ }^{6}$ A very good survey of this debate, with Winckelmann as its starting-point, is to be found in $\mathrm{H}$. B. Nisbet, 'Laocöon in Germany: The Reception of the Group since Winckelmann', OGS, 10 (1979), 22-63. The title gives a very good clue as to Winckelmann's place in literary history.

${ }^{7}$ Variations upon this formula abound in Winckelmann. The likely source for most readers would be his Gedanken über die Nachahmung der griechischen Werke in der Malerei und Bildhauerkunst, Dresden 1955, where it appears in a number of formulations in connection with the Laocöon group.

${ }^{8}$ Winckelmann was introduced to Geßner's work by Johann Jacob Volkmann. He later began a correspondence with the man himself and famously read aloud from his work whilst climbing Mount Etna. See Briefe, ii, 161; ii, 113; ii, 407.

${ }^{9}$ See Alex Potts, 'Winckelmann's Construction of History', Art History, 5/4 (1982), 377-407 and Michael Podro, The Critical Historians of Art, second edition, New Haven 1986.

${ }^{10}$ See Hans Zeller, Winckelmanns Beschreibung des Apoll im Belvedere (Zürcher Beiträge zur deutschen Literatur- und Geistesgeschichte, 8), Zürich 1955 and Hanna Koch, 'Johann Joachim Winckelmann: Sprache und Kunstwerk', Jahresgabe der Winckelmann-Gesellschaft, 1956-7 (Berlin 1957). These two investigations of Winckelmann's language, taken together, offer the best introduction to the development of his characteristic language for art.
} 
Michel Foucault was the starting-point. I was particularly interested in the early pages of his history of sexuality. In his historical survey he describes the increasing dominance (his starting point is the seventeenth century) of, as he calls it, the 'legitimate and procreative couple' as a norm for sexual behaviour. ${ }^{11}$ And so 'sterile behavior carried the taint of abnormality; if it insisted on making itself too visible, it would be designated accordingly and would have to pay the penalty' (History of Sexuality, pp.3-4). The 'solution' was seen to be marginalisation of the people concerned, followed by their reintegration into society after submission to some kind of deprogramming, and here Foucault was, of course, largely thinking of the role of the mental hospital as an assumed means to achieve both ends. Otherwise the hope was that the marginalised would take their 'infernal mischief elsewhere' (ibid., p.4) - underground or perhaps best abroad. Perhaps some dark intuition of this took Winckelmann south to Italy - and so nearer to Greece, where homosexuality, scholarship and art had historically proven a productive combination. ${ }^{12}$ It was conveniently there in Rome that he could also see the objects about which he had already begun to write. And in this writing we perhaps see the proof of one of Foucault's other assertions. Foucault finds himself investigating a rather paradoxical situation; even as suspect sexual behaviour, and indeed even as the whole business of sex, 'normal' or otherwise, was being repressed in core areas of everyday life (he mentions the strange silence which developed historically between parents and children on all matters sexual), discourses which implied sex were multiplying or being intensified, particularly where power was to be exercised. Locations were established in which the discourse could be controlled. Here Foucault discusses the detailed confession of sin in religious practice and medical definitions of psychological normality as key examples of the policing of sexual questions by proxy - that is, without indicating what the real issue was. And so a second category of repression can be identified. Where the problem of sexuality cannot be simply confined or ignored it can at least be 'driven out of hiding and constrained to lead a discursive existence'. Luckily given my topic - Foucault was certain 'that where sex is concerned, the most long-winded ... of societies is our own' (ibid., p.33). This prolixity seems also to be very apparent in discourses evidently more remote from the centre of power, and less rigorously policed. It surfaces very clearly in eighteenth-century aesthetics, a discourse particularly amenable to it. Talking about art was, then, perhaps not quite as harmless as it might have seemed. Given Winckelmann's importance to the development of this field and particularly to the development of the language of art, we have perhaps located a place where - in this case - homosexuality could find a voice. The question is, whether it was being kept under control or

\footnotetext{
${ }^{11}$ Michel Foucault, The History of Sexuality, I: 'An Introduction', Harmondsworth 1978, p.3. (All subsequent references in the body of the text in the form: History of Sexuality, page no.)

${ }^{12}$ See Kenneth James Dover, Greek Homosexuality, London 1978.

(c) Blackwell Publishers Ltd 1999.
} 
whether it might from this discursive outpost begin to subvert established positions. After all, Winckelmann's aesthetic agenda becomes a required part of a gentleman's education; it could determine at least the style of a court. Perhaps it could also subtly alter its substance? At the very least, it provided an important outlet for Winckelmann's sexuality, a fact overlooked until recently by almost all secondary literature on the subject. This might, of course, indicate a difficulty in dealing with sexuality even more profound than that pointed out by Foucault; the issue of sexuality, even in its discursive manifestation, would appear to be something with which we are uncomfortable even today.

This leads me to my second theoretical impulse, perhaps a less obvious one: contemporary or near-contemporary gay (liberation) art (particularly photography of the body) and the writing it produces. This may seem a daring comparison, and I am not claiming that the Venice of the 1750s could be compared with the Venice Beach of the 1970s. I am merely pointing out that writing about beautiful things need not be quite as harmless an occupation as it might at first seem. In a fine article on this subject Michael Worton indicates the revolutionary potential of such work. ${ }^{13}$ His starting point could be from Foucault:

Western Society is heavily invested in portraying masculinity as heterosexual, white, and dominant. It therefore has created and maintains representations of such a masculinity which come to function as mainstream, collective ideals, thereby pressuring people into behaving in ways which are often constraining and against their own individual best interests, but which have reassuring adaptive structural effects, facilitating integration into a society that is largely divided along gendered lines. ('Celebration or Effacement', p.15)

With Foucault, Worton believes that this situation can only be changed by taking control of the discourse, by changing the rhetoric of masculinity, something that he argues happened in modern gay photography and the criticism it produced (e. g. the art and the responses to the art of Robert Mapplethorpe). If, as often happens, the artist experiments with representations of the ideal male body - with the mythology of masculinity - he can force his viewer into response, into questioning the identity of that ideal and ultimately of himself. In this process, as 'collective phallic identity is effaced and as individual mythic specificity is celebrated, the male nude photograph enables us to rewrite the scenario of masculinity and to see the body of masculinity as a corpus on which ever new runes may be traced' ('Celebration or Effacement', p.23). This is, of course, a grand claim and a possibility which many have yet to discover. But if we look at Winckelmann in these terms, his subversive potential - which could never

\footnotetext{
${ }^{13}$ Michael Worton, 'Celebration or Effacement? Imag(in)ing the Body of Masculinity', in Image into Text: Text into Image, ed. Florian Krobb and Jeff Morrison, Amsterdam 1997, pp.15-23. (Further references in the body of the text in the form: 'Celebration or Effacement', page no.)
}

(c) Blackwell Publishers Ltd 1999. 
be realised under the prevailing socio-political conditions - becomes clear. His own self-discovery is inscribed in his writing on art which was for many readers the sole means of access to ancient art. Art was revealed to people in its transformative power. And, perhaps taking things further than the radical modern photographer, he wished to show this power by examining precisely those works which were at the core of Western notions of masculinity - those representing Greek athletes or gods.

Winckelmann's sexual agenda is clear even before we arrive at his famous descriptions. Much of his work in Italy involved tutoring visiting noblemen in art history. Often this was unpleasant work as the men rushed around Rome before heading for the brothels of Naples. Many of them showed 'nicht einmal ein Zeichen des Lebens' as Winckelmann described works to them. ${ }^{14}$ But occasionally he found kindred spirits such as Friedrich Rudolf von Berg to whom - tellingly - he dedicated the Abhandlung von der Fähigkeit zur Empfindung des Schönen (KS, 211-13). ${ }^{15}$ (In fact ultimately Berg was to prove a disappointment.) In the essay for Berg, from which the quotations below are taken, he describes the qualifications appropriate to a student of art and absent in so many of his visitors. Money and leisure are high on the list - as we can understand, given the location of the great works of art. And he only deals with men - again in line with the socio-political realities of the time and not just with his personal preference. Then come more elusive aspects of the 'Fähigkeit'. Adapting a commonplace theory of the time, Winckelmann identified body with soul - 'da wir insgemein denken wie wir gemacht sind'. This amounts to a requirement that his pupils should be beautiful, rich men. What is more, they must be young, beautiful, rich men before they succumb to the 'verworrene Rührungen' of adolescence. These men would then be brought to Italy after a period of preparatory study for individual tutoring. At its simplest we could have here a pragmatic, eighteenth-century adaptation of the Socratic method. But it is surely more than this. We have a striking coincidence of sexual agenda and pedagogic method, a coincidence so strong that the two issues become inseparable.

This is no less the case when we arrive at the works of art themselves. Winckelmann's famous descriptions were aimed in large part at bringing famous works of art to a deprived public abroad. It is suprising, therefore, how little effort goes into the business of actually describing the objects themselves. It is rather the relationship with the work which is described. Within this the power relationship between work and viewer varies. Winc-

\footnotetext{
${ }^{14}$ The best example of this tendency is Frederick Calvert (Lord Baltimore) who particularly annoyed Winckelmann. Rehm collects references to him at Briefe, ii, 479. This reference, like those that follow immediately, is taken from the Abhandlung von der Fähigkeit zur Empfindung des Schönen at $K S, 211-13$.

${ }^{15}$ See Wolfgang Leppmann, Winckelmann: Eine Biographie, Frankfurt a. M. 1971, pp.238-9 for an account of this failed relationship. He draws interesting parallels with an earlier failed relationship with Lamprecht.

(ㄷ) Blackwell Publishers Ltd 1999.
} 
kelmann can be deferential towards the work. Describing the difficulty of writing one description, he says:

Die Kunst selbst müßte mir rathen, und die Hand leiten, die ersten Züge, welche ich hier entworfen, künftig auszuführen. Ich lege den Begriff, welchen ich von diesem Bilde gegeben habe, zu dessen Füßen, wie die Kränze derjenigen, die das Haupt der Gottheiten, welche sie krönen wollten, nicht erreichen konnten. (KS, 268)

But this distance can be overcome and a relationship established, one based on extreme intimacy. For: 'Die Fähigkeit das Schöne in der Kunst zu empfinden, ist ein Begriff, welcher zugleich die Person und Sache ... in sich faßt, welches ich aber in eins schließe' $(K S, 217)$. And so: 'Das wahre Gefühl des Schönen gleichet einem flüßigen Gipse, welcher über den Kopf des Apollo gegossen wird, und denselben in allen Theilen berühret und umgiebt' (ibid.). As if sensing that this intimacy could be misunderstood, Winckelmann immediately qualifies it. The last passage cited continues: 'Der Vorwurf dieses Gefühls ist nicht, was Trieb, Freundschaft und Gefälligkeit anpreißen, sondern was der innere feine Sinn, welcher von allen Absichten geläutert seyn soll, um des Schönen willen selbst, empfindet' (ibid.). The 'Gefühl des Schönen' remains ill-defined in this and the rest of Winckelmann's work, and we cannot help feeling that it has a similar source to other feelings of his. This disclaimer certainly reminds us of another statement made in connection with von Berg. His relationship with him was 'rein von allen ersinnlichen Absichten' (KS, 212) in the official version - though the Winckelmann correspondence might lead us to see it differently, as indeed might a reading of the planned more blatant dedication of the Abhandlung to Berg. ${ }^{16}$ This does not, of course, devalue the disclaimed feelings informing Winckelmann's private life and his study of art; and in any case we celebrate with him the transformative power of art. Talking of the Apollo Belvedere he says:

Ich vergesse alles andere über dem Anblick dieses Wunderwerks der Kunst und ich nehme selbst einen erhabenen Stand an, um mit Würdigkeit anzuschauen. Mit Verehrung scheint sich meine Brust zu erweitern und zu erheben ... und ich fühle mich weggerückt nach Delos und in die Lycischen Hayne, Orte welche Apollo mit seiner Gegenwart beehrte: denn mein Bild scheint Leben und Bewegung zu bekommen, wie des Pygmalions Schönheit. (KS, 268)

We are a long way here from the 'edle Einfalt und stille Größe' which we might have been expecting to find portrayed in works of art and which we might also expect to be a feature of the reception of art. Winckelmann's descriptions are dynamic and perhaps at their core erotic. The reference to the Pygmalion myth - where life is given by a kiss - is vitally important

${ }^{16}$ See Briefe, ii, 349 for an admission that the planned dedication was 'etwas frey geschrieben'. 
here. And it is not just the work of art which is brought to life in this depiction; the observer Winckelmann feels himself physically and spiritually transformed, inspired - kissed? - by the statue. The mutuality in the relationship is unequivocal and cannot be explained easily in terms of his academic appreciation of an historical artefact. The reciprocal relationship between the work of art and the observer can be identified repeatedly in Winckelmann's writing on art. It is even reflected in the verb forms which are employed in the descriptions. Often there is an almost flirtatious interaction between observer and work of art reflected in alternating grammatical activity and passivity. ${ }^{17}$ In the most extreme formulation Winckelmann describes himself becoming a part of the work of art he describes. The description of the Belvedere Torso $(K S, 169-73)$ is extreme even by Winckelmann's standards but this extremity is, we are shown, facilitated by the work of art itself. The torso is a fragment and as such it encourages Winckelmann to reconstruct it imaginatively. However, the end result of this imaginative engagement, the description, ultimately tells us much more about Winckelmann than about the object itself. On the basis of his inspection of the torso, Winckelmann is quite clear about what he is seeing (or perhaps wanting to see): 'Ich sehe ... die unüberwundene Kraft des Besiegers der gewaltigen Riesen, die sich wider die Götter empöreten und in den phlegräischen Feldern von ihm erleget wurden' (My emphasis). These events are not present in the depiction but the statue suggests them. And yet Winckelmann does not see himself as actively imposing an interpretation, since the work responds at once: 'zu gleicher Zeit stellen mir die sanften Züge dieser Umrisse, die das Gebäude des Leibes leicht und gelenksam machen, die geschwinden Wendungen desselben in dem Kampfe mit dem Achelous vor' (My emphasis). Winckelmann did not need to overwork his interpretative faculties since after all 'in jedem Theile dieses Körpers offenbaret sich ... der ganze Held' (My emphasis). The relationship with the work of art, a creative symbiosis, offers revelation. But before we are drawn into seeing his absorption by art as above all a spiritual process - a quasi-religious experience - it is important to look at the description of the side of the same statue. Typically the muscular side of the torso is not described as static; the muscles imply movement and it is this that he describes. They remind Winckelmann of waves, rising and then falling. And the viewer finds himself drawn in by this wave motion until finally 'unser Blick wird gleichsam mit verschlungen', swallowed up by the waves. This highly sensual imagery gives us a very strong sense of what it is to be at one with art - and one which is much more powerful and convincing than the quasi-religious account of the experience superimposed upon it which by its very nature understates the sensual, as it were measurable relationship with art, in favour of seeing art merely as a pathway to God (however defined). In concluding his description Winckel-

\footnotetext{
${ }^{17}$ See Jeffrey Morrison, Winckelmann and the Notion of Aesthetic Education, Oxford 1996, pp.34-68, particularly pp.45-62. 
mann does suggest that we should not overrate the sensual aspect of the experience of art:

Diese vorzügliche und edle Form einer so vollkommenen Natur ist gleichsam in die Unsterblichkeit eingehüllet, und die Gestalt ist bloß wie ein Gefäß derselben; ein höherer Geist scheinet den Raum der sterblichen Theile eingenommen, und sich an die Stelle derselben ausgebreitet zu haben.

But the 'Gefäß' sems to have a more potent role to play than the incidental one imagined here. And the relationship with whatever spirit inhabits the works of art would seem more dynamic than the one pictured above. Whilst the religious category provides convenient metaphors for the transformative experience of art, they are, as will be seen, clearly not wholly appropriate. Foucault perhaps gives us the crucial hint as to precisely which energy informs this discourse. Might it just be more convincing to see Winckelmann's dream of being at one with art as a projection of his desire to see his sexuality fully realised? Could it be that Winckelmann the aesthetician was not just also gay but fundamentally so, even as an aesthetician? His sexuality had to be repressed for him to function effectively within society; the fact that he was known by many to be gay did not mean that he had the liberty to be so. We need look no further than his correspondence with Riedesel. In these letters it becomes clear that Riedesel is aware of his teacher's sexuality but it is clearly something which is to be treated with discretion - and we must remember that his dedication of the Abhandlung to Berg could never appear. ${ }^{18}$ In his experience of art Winckelmann could at least imagine stepping outside of his narrowly defined social self and he could experience personal growth through his relationship with art. It could be called a love story, but sadly the love could only exist at the level of metaphor and it was mediated though art. The discourse of aesthetics can, it would appear, accommodate these projections of repressed sexuality but in the final analysis it remains discourse.

At this stage it would be useful to look more closely at the component parts of Winckelmann's rhetoric rather than at its internal dynamics. As was suggested briefly above, Winckelmann's work owes a great deal to that of Greek theorists as well as artists. Plato's Socrates, Platonic theory generally (and the neo-Platonic version of that theory) are central here. The transition into the eighteenth century is one which the theories survive well; further, we do not have the impression - for obvious reasons - that the homosexual agenda has been painfully grafted on to art theory. This language sits so well with Winckelmann that he can employ it to deal with aspects of 'real life' outside the arts. At times it can be difficult to distinguish whether Winckelmann is talking about art or life, such is the degree of shared vocabulary. Many of the benchmarks for art and life

${ }^{18}$ See Briefe, ii, 296; ii, 312 for Riedesel's awareness of his teacher's sexuality. 
appear to be shared. I am thinking here of Winckelmann's interest in the boy Niccolo Castellani. He was based in Naples and Winckelmann asked his friend Riedesel to report back to Rome on the current state of his looks. The boy is presented almost as an art-historical phenomenon - his beauty analysed in stylistic and historical terms - and yet the subtext is clear enough for it to be hard to accept, as Winckelmann would have us believe, that 'keine Neigung war so rein als diese' (Briefe, ii, 334-5) ${ }^{19}$ The language of aesthetics can communicate things other than the experience of art, it seems. And for as long as the art theory is a modified version of the Ancient Greek one, we as readers have little sense of discomfort.

This Greek rhetoric is not, however, the only one which can be immediately identified. We also cannot miss in his writing the influence of Pietism, particularly in the more ecstatic passages where Winckelmann is esoterically exploring his relationship with God through art. However, given the specific sensual aspect of Winckelmann's aesthetic, the rhetoric of Pietism can seem a little out of place. Boyle captures our sense of unease beautifully. Speaking in general terms, he observes that Winckelmann's descriptions are 'painted in seductive idealisation' ${ }^{20}$ But this seduction involves manipulation of an established rhetorical code. According to Boyle: 'the language of Pietist self-scrutiny and religious transport, ingrained in him [Winckelmann] since his childhood, he put in the service of a sensualist paganism'. ${ }^{21}$ The liberties which Winckelmann had to take with established patterns of rhetoric could be viewed as an entirely negative enterprise. A shoddy workman working with inappropriate tools. But surely it is best viewed positively. We are in the first instance seeing the emergence (out of other related rhetorical schemes) of a German language for art. Furthermore, we are seeing the development of a language to deal with homosexual experience. I think that we are back with Foucault. Whilst homosexuality may have been driven to all intents and purposes out of the everyday realm, it could in its apparently primarily discursive life begin to explore new possibilities. Winckelmann's experience of the expansion of self through complete absorption into another would seem like a vision of a perfect relationship, one which he would scarcely have had the opportunity to pursue, at least in the open. Any experience of personal growth was achieved through the workings of the imagination captured in the discourse of aesthetics. But at least the effective prohibition of his brand of sexuality did not mean total denial; it could be displaced into a safer place - from society's perspective.

The interdependence of the rhetorics of aesthetics, religion and of homosexuality in the case of Winckelmann should, then, be clear. But what of the consequences beyond Winckelmann? What of the potential for change in others which Worton, albeit from a very different perspec-

\footnotetext{
${ }^{19}$ Ibid.

${ }^{20}$ Nicholas Boyle, Goethe: The Poet and the Age, I, Oxford 1991, p.28.

${ }^{21}$ Ibid.

(C) Blackwell Publishers Ltd 1999
} 
tive, might have led us to expect? Did others identify with Winckelmann's engagement with art and attempt to develop a relationship with it in a similar manner? Did people realise that something fundamentally different was happening in the presentation of canonical works of art, that this was not someone who admired the famous bodies from afar and revered them for their long-established heroic properties? Even those whose sexual agenda was not the same as his would surely notice that something new was happening. Sadly, this seems true only to a limited degree and even the evidence from Winckelmann's immediate circle is thin. Worthy pupils such as Johann Hermann von Riedesel were able to cast off the influence of Winckelmann shortly after the latter's death. Written works produced in the style of Winckelmann and with a content which owed much to him were suddenly replaced by work in French without a focus on the arts even when Riedesel found himself in Athens. ${ }^{22}$ In fact, even the early work which was effectively written for Winckelmann shows little engagement with art; the famous formulae and variations upon them are repeated, but the study of art does not lead anywhere. It is an accumulation of information and in its published form an ostentatious display of 'culture'. There is no evidence that art worked for him in anything like the manner that it did for Winckelmann. We ultimately suspect that the interest in art was merely a fashion statement, for when Riedesel visits Scotland his letters suddenly reveal a language descended directly from Burke; a different gloss of culture is applied to his writing. Of course, none of this means that we can blame Riedesel for some failure. The language of aesthetics is merely being used to a different end, so that part of its potential has to remain unrealised.

This gap between teacher and pupil is still wider in the case of another Winckelmann pupil, Johann Jacob Volkmann. He did much to spread the Winckelmannian gospel in popular form through his guidebooks. Winckelmannian epithets are applied like the stars in a modern Michelin guide. If the architecture of that building is both 'einfältig' and 'edel', then you just have to visit. Volkmann was apparently immune to what the study of art could mean; perhaps it did not need to mean as much to him as it did to Winckelmann. He does, however, provide us with one highly illuminating anecdote. On a famous occasion he confused one of Winckelmann's transports of delight at the prospect of a work of art with a bout of malaria. ${ }^{23}$ This does more than tell us how carried away Winckelmann could get. It is interesting, particularly after a reading of Foucault, that another brand

\footnotetext{
${ }^{22}$ See Johann Hermann Freiherr von Riedesel, Reise durch Sicilien und Großgriechenland, Zürich 1771. This work is written very much in the spirit of Winckelmann. His Remarques d'un voyageur moderne au Levant, Amsterdam 1773 mark the first break, and the Scottish letters published in the Reisen des Freiherrn Johann Hermann Riedesel zu Eisenbach, Jena 1830 mark a complete change in critical perspective.

${ }^{23}$ See Johann Jacob Volkmann, Historisch-Kritische Nachrichten von Italien, Leipzig 1770-1. For the malaria incident see a note in Winckelmanns Briefe an seine Freunde, ed. K.W. Daßdorf, Dresden 1777-80, II, p.175.
}

(C) Blackwell Publishers Ltd 1999. 
of rhetoric had to be employed to capture Winckelmann's responses. The description in medical terms neutralises the disruptive potential of an understanding of Winckelmann's response to art: the medical 'explanation' makes a better joke and closes the matter without further ado. Volkmann surely knew the man better than this; and on the basis of the material presented so far, surely we do too.

Alone amongst his (near-) contemporaries it was Goethe who experienced art as Winckelmann had, albeit on a different basis. Even a brief review of his developing relationship with art as detailed in his reports from Italy is illuminating. First: the preparatory study. In his luggage was the usual assortment of guides and also a single volume of Winckelmann. He did not, however, take any art history with him but rather an edition of Winckelmann's letters. His interest was in the development of the man rather than in the historical/stylistic assessment of artefacts. This tendency re-emerges in his late publication Winckelmann und sein Jahrhundert, where he writes about the personality of the man whilst others review his academic work. ${ }^{24}$ When Goethe writes about art he talks in terms of the difficulty of developing a relationship with it, but the effort is rewarded as one moves beyond stunned amazement at the beauty of the objects to experience 'ein Mitleben und näheres Gefühl des Werthes der Sachen' ${ }^{25}$ Moments of aesthetic satisfaction are akin to intimate conversations. He responds to the 'Gegenwart der Dinge' and so is 'den ganzen Tag in einem Gespräch mit den Dingen' (Werke, iii.i, 219). Unsurprisingly, his writing on art reveals a verbal dynamic akin to that identified in Winckelmann. ${ }^{26}$ He, like Winckelmann, saw himself transformed by art, an experience perhaps most compactly formulated in the statement: 'ich bin wirklich umgeboren und erneuert und ausgefüllt' $(I R, 359)$. The reciprocity in the relationship with art is shown in his acknowledgement that he is being shaped by art in something of the manner in which a work of art is shaped by a man, which is 'warum ich mich hämmern und bearbeiten laße' (Werke, iv.8, 116). And yet even with his apparently safer sexual orientation, he did not necessarily present a comfortable picture in his response to art. ${ }^{27}$ In yet another shift in rhetoric we are shown at one point in the Italian travels how a gallery custodian can only explain Goethe's enthusiasm for art by reference to another discourse. The woman represented in the statue being viewed must remind him of his lover $(I R, 150)$. To the modern reader this may seem innocent enough but, if we believe Foucault, then there is a key admission involved. Implicit in the custodian's response

\footnotetext{
${ }^{24}$ See Ernst Howald (ed.), Winckelmann von Goethe, Erlenbach 1943.

${ }^{25}$ All Goethe references are to the Weimar edition: Johann Wolfgang von Goethe, Werke, Weimar 1887-1919, or to the convenient Italienische Reise, ed. Peter Sprengel, Munich 1986. Subsequent references appear in the text in the form: Werke, vol. no., page no., or: $I R$, page no. This quotation is taken from Werke, iv.8, 100.

${ }^{26}$ For a more detailed study see Morrison, Winckelmann (note 17, above), pp.209-48.

${ }^{27}$ Opinions vary on Goethe's sexuality. Cf. Boyle, Goethe (note 20, above), index, under 'homosexuality' and 'sexuality'. It is clearly not a matter which can be dealt with at any length here.

(c) Blackwell Publishers Ltd 1999.
} 
is an awareness that the rhetoric of art may contain the rhetoric of sex and it may not be without implications. Whilst it is clearly beyond the scope of this paper to offer a full discussion of the topic, it would certainly be interesting to investigate Goethe's writing on art as a site for exploration of his sexuality.

Discussion of the sexual subtext to Winckelmann's writing on art was strategically avoided even well into the twentieth century. We need look no further than the wealth of idealising biographical treatments of Winckelmann which fail to mention his sexuality in connection with his life, let alone his work. A process of domestication was under way which strangled the life out of Winckelmann, though it did have its amusing moments. There is something particularly satisfying about the attempts under the Nazi regime or Socialist rule in the GDR to construct a view of Winckelmann as a Germanic hero, to make him fit in or even act as a model for future generations. ${ }^{28}$ Certainly, the energy which I located at the core of his work was destined to remain latent, unnoticed, in later generations and so the potential which engagement with art could have, according to Winckelmann (and much later Worton), was rarely realised. Winckelmann might have fundamentally changed our understanding of the ontology of art and of aesthetic experience by revealing his own growth through exposure to it. He might have changed our basic understanding of the (above all masculine) heroic element in statuary. Apollo or Hercules with Winckelmann by their side - which is how he imagined them - are not heroic figures in the manner that we think we know them. They would seem to be Winckelmann's sexual and spiritual helpers, bringing life to the discourse of aesthetics, if sadly at the cost of missing life elsewhere. Suddenly the notions of noble simplicity and calm grandeur seem very dead.

${ }^{28}$ There is a largely unsorted collection of newspaper cuttings from these periods in the collection of the Winckelmann-Gesellschaft, Stendal. They make very amusing reading. 